\title{
Konsolidasi Komunal sebagai Mitigasi Konflik Agama di Jawa Timur
}

\author{
Abdul Fatah \\ Muhammadiyah University of Surabaya, Indonesia \\ efat77@gmail.com
}

\begin{abstract}
Indonesia adopts democracy based on the rule of law as it is guaranteed in the constitution. But, the practice of violations of Freedom of Religion and Belief (KBB) still frequently occurs in Indonesia, including in the province of East Java. As a result of intolerance under the ground of religion and belief, social conflict is inevitable. There are several alternatives as a means to establish transitional justice in the aftermath of conflict, such as truth finding, independent and impartial tribunal, mainstreaming collective consciousness on the importance of diversity, and utilization of policy to counter social conflict. Nevertheless, another important aspect is the need of communal consolidation in the aftermath of intolerant practice and social conflict. Thus, communal consolidation which involves interested parties should be seen as an instrument of conflict mitigation under the ground of religion in East Java.
\end{abstract}

KEYWORDS: The Rule of Law, Government, Freedom of Religion and Belief.

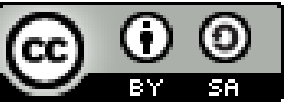

Copyright $₫ 2018$ by Author(s)

This work is licensed under a Creative Commons Attribution-ShareAlike 4.0 International License. All writings published in this journal are personal views of the authors and do not represent the views of this journal and the author's affiliated institutions.

\section{HOW TO CITE:}

Fatah, Abdul. "Konsolidasi Komunal sebagai Mitigasi Konflik Agama di Jawa Timur" (2018) 5:1 Lentera Hukum 115-126.

Submitted: January 18, 2018 Revised: February 09, 2018 Accepted: April 03, 2018 


\section{PENDAHULUAN}

Indonesia merupakan negara hukum yang seringkali direfensikan pada rule of law atau rechtsstaat yang menjamin hak asasi manusia (HAM). Hal demikian sebagaimana dituangkan di dalam Undang-Undang Dasar Negara Republik Indonesia Tahun 1945 (UUD NRI Tahun 1945) sebagai konstitusi yang berlaku di Indonesia. Di Indonesia tidak ada pengaturan baku terkait dengan konsep negara atau negara berdasarkan hukum. Akan tetapi, penegasan Indonesia sebagai negara hukum diiringi dengan pengaturan tentang HAM yang lebih luas dan komprehensif pada Bab khusus, yaitu Bab XI A yang terdiri dari Pasal 28A-28J. Dalam bab ini, semua aspek hak asasi mendapatkan jaminan. Aspek tersebut tidak hanya hak di bidang sipil dan politik, tetapi juga hak atas kesejahteraan masyarakat seperti hak di bidang ekonomi, sosial dan budaya. Pengaturan HAM dalam UUD NRI Tahun 1945 merupakan komitmen negara untuk memenuhi syarat keberadaan Indonesia sebagai negara hukum. ${ }^{1}$

Ide negara hukum rechtsstaat sesungguhnya sejak lama telah dikembangkan oleh para filosuf Yunani Kuno yang pada pokoknya bertumpu pada sistem hukum Eropa Kontinental yang mulai populer pada abad ke-17 karena pada saat itu situasi dan kondisi sosial politik di Eropa didominasi oleh absolutisme. Ide negara hukum rechtsstaat ini sesungguhnya dipelopori oleh Immanuel Kant dan Frederich Julius Stahl. Kant memahami negara hukum sebagai negara penjaga malam (nachtwakersstaat). Artinya, negara itu bertugas untuk menjaga ketertiban dan keamanan masyarakat.

Pada awalnya, Plato berpendapat bahwa mungkin mewujudkan negara ideal untuk mencapai kebaikan yang berintikan kebaikan. Karena itu, kekuasaan harus dipegang oleh orang yang mengetahui kebaikan, yaitu seorang filosof (the philosopher king). Selanjutnya, Plato menyatakan bahwa yang dapat diwujudkan adalah bentuk paling baik kedua (the second best) dengan menempatkan supremasi hukum. Pemerintahan yang mampu mencegah kemerosotan kekuasaan seseorang adalah pemerintahan oleh hukum. ${ }^{2}$ Adapun tujuan negara menurut Aristoteles adalah untuk mencapai kehidupan paling baik (the best life possible) yang dapat dicapai dengan supremasi hukum. ${ }^{3}$ Sejak Plato menulis "Nomoi," E. Kant memaparkan prinsip-prinsip negara hukum (formil). J. Stahl mengetengahkan negara hukum (materil), Dicey mengajukan "Rule of law". Ringkasnya, merupakan suatu negara yang ideal pada abad ke20 ini, jika segala kegiatan kenegaraan didasarkan pada hukum. ${ }^{4}$

$1 \quad$ Majelis Permusyawaratan Rakyat RI, Panduan Pemasyaratakatan Undang-Undang Dasar Negara Republik Indonesia Tahun 1945 dan Ketetapan Majelis Permusyawaraatn Rakyat Republik Indonesia, Jakarta: Sekretariat MPR RI, 2001, hlm 166.

2 A. Saman Maggalatung, Makalah, Indonesia, Negara Hukum Demokrasi, Bukan Negara Kekuasaan Otoriter, hlm. 2.

3 Jimly Asshiddiqie, Hukum Tata Negara e Pilar-Pilar Pilar Demokrasi, Serpihan Pemikiran Hukum, Media dan HAM, Jakarta: Konstitusi Perss, hlm. 129

4 Padmo Wahyono, Pidato Pengukuhan sebagai Guru Besar Fakultas Hukum UI tanngal 17 November 1979. Seperti dikutip dalam bukunya sendiri, Indonesia Negara berdasarkan Atas Hukum, Jakarta: Ghalia Indonesia, hlm. 7 
Pengertian tersebut selalu berkembang sesuai dengan tingkat kecerdasan suatu bangsa. Oleh karena itu, Padmo Wahyono berpegang pada perumusan sebagaimana yang digariskan oleh pembentuk Undang-Undang Dasar, yaitu Indonesia ialah negara yang berdasarkan atas hukum. Dengan rumusan "Rechtsstaats" dengan anggapan bahwa pola yang diambil tidak menyimpang dari pengertian negara hukum pada umumnya yang disesuaikan dengan keadaan Indonesia. Artinya digunakan dengan ukuran pandangan hidup maupun pandangan bernegara. ${ }^{5}$ Dengan demikian, cukup jelas bahwa Indonesia adalah negara hukum yang demokratis. Hanya saja pada tingkat implementasinya memang masih diperbincangkan oleh banyak kalangan. Di dalam UUD NRI Tahun 1945, terdapat dua hak dasar yang saling bersinggungan dan mempunyai keterkaitan erat, yakni hak diperlakukan sama di depan hukum (equality before the law) dan hak atas keadilan (access to justice).

Akses terhadap keadilan (aceess to justice) dan persamaan di depan hukum (equality before the law) merupakan rezim HAM yang harus dipenuhi sebagai kerangka desain negara yang demokratis. Pengaturan akan akses terhadap keadilan dan persamaan di depan hukum dalam UUD NRI Tahun 1945 berlandaskan pada Pasal 27 ayat (1), Pasal 28D ayat (1), dan Pasal $28 \mathrm{H}$ ayat (2). Konsekuensinya, negara menjadi wajib hadir untuk melakukan pemenuhan, penghormatan, perlindungan, dan pemajuan terhadap kedua hal tersebut. Kewajiban dari negara ini juga dilandasi oleh pengaturan pada Pasal 28I ayat (4) UUD NRI Tahun 1945. Negara, terutama pemerintah, dalam rangka melaksanakan kewajiban untuk melakukan pemenuhan, penghormatan, perlindungan dan pemajuan HAM, diwujudkan dalam bentuk kebijakan hukum (legal policy). Akan tetapi, dalam jaminan yang diberikan oleh negara tersebut realitas pelanggaran HAM bagi kelompok rentan masih saja terjadi bahkan mengalami peningkatan yang signifikan termasuk di Jawa Timur. Dalam posisi ini kelompok rentan menjadi korban. ${ }^{6}$ Kelompok rentan ${ }^{7}$ dimaksud misalnya kelompok perempuan, minoritas agama dan etnis, dan kelompok inklusi sosial lainnya. Kasus pelanggaran terhadap hak atas

5 Ibid.

6 Menurut Declaration of Basic Principles of Justice for Victims of Crime and Abuses of Power tahun 1985, korban didefinisikan sebagai orang, perseorangan atau bersama-sama/kelompok, yang menderita kerugian, termasuk kerugian fisik atau mental, penderitaan emosional, kerugian ekonomis atau pelemahan substansial dari hak-hak dasar mereka, melalui tindakan atau kelalaian yang merupakan pelanggaran terhadap hukum yang berlaku di negara-negara anggota termasuk hukum-hukum yang melarang penyalahgunaan kekuasaan yang bersifat pidana. Menurut UU No. 13 Tahun 2006 tentang Perlindungan Saksi dan Korban, korban didefinisikan sebagai orang yang mengalami penderitaan fisik, mental, dan/atau kerugian ekonomi yang diakibatkan oleh suatu tindak pidana.Korban dalam pengertian ini termasuk mereka yang menjadi korban pelanggaran HAM. Sehingga, korban merupakan pihak pihak yang menderita dan dirugikan sebagai akibat tindak pidana, penyalahgunaan kekuasaan, dan pelanggaran HAM.

7 Secara sederhana, kelompok rentan adalah kelompok yang lebih mudah terlanggar hak-haknya sehingga mereka lebih mudah menjadi korban (baik secara individu maupun kelompok) dikarenakan kekhususan/kekhasan yang dimilikinya. Rentan mengandung pengertian adanya kekhususan tertentu yang menyebabkan mereka (kelompok rentan) lebih berisiko terlanggar hak-haknya/lebih berisiko menjadi korban sehingga mereka memerlukan perlindungan yang lebih dibandingkan mayoritas masyarakat pada umumnya. Yang termasuk kelompok rentan adalah kelompok agama/keyakinan minoritas, difabel dan LGBT. 
kebebasan beragama dan berkeyakinan juga cukup tinggi di Jawa Timur. Hak atas kebebasan beragama dan berkeyakinan adalah hak untuk memilih, memeluk dan menjalankan agama dan keyakinan. ${ }^{8}$

Dengan banyaknya pelanggaran bagi kelompok rentan di Jawa Timur, khususnya adalah kelompok minoritas keyakinan yang nyata-nyata mengurangi penikmatan HAM dalam bidang kebebasan beragama dan berkeyakinan memerlukan kajian yang mendalam dan detail terkait dengan upaya apa yang dapat dilakukan sebagai desain upaya penanganan. Kasus-kasus yang bersinggungan dengan dengan keyakinan tersebut oleh masyarakat Jawa Timur dipandang sebagai konflik agama. Dengan adanya konflik $^{9}$ agama membutuhkan suatu alat mitigasi konflik yang terjadi. Tipologi masyarakat Jawa Timur adalah guyub, yang mana keguyuban ini memiliki komunalitas sehingga mitigasi konflik yang dapat digunakan adalah konsolidasi komunal yang melibatkan semua pihak berkepentingan dengan didasarkan pada pencapain kebenaran.

\section{POTRET HAK ASASI MANUSIA DI JAWA TIMUR}

Dalam konteks perlindungan terhadap hak-hak kelompok minoritas, Jawa Timur memiliki catatan yang patut dipertimbangan. Hingga 2015, indeks demokrasi Jawa timur tegolong rendah. ${ }^{10}$ Di samping didasarkan pada kriteria pelembagaan demokrasi, catatan indeks demokrasi ini juga mengacu pada beberapa aspek penting dalam pemenuhan HAM. Bahkan, laporan SETARA Institute 2016 mencatat Jawa Timur sebagai wilayah pelanggar HAM nomor tiga di bawah Jawa Barat dan DKI Jakarta. ${ }^{\text {ll }}$

Ada beberapa catatan yang membuat Jawa Timur termasuk wilayah yang tidak baik catatan HAM-nya. Pemerintah Provinsi Jawa Timur termasuk pihak yang paling cepat membuat larangan terhadap komunitas Ahmadiyah. Melalui Surat Keputusan Gubernur Jawa Timur No 188/94/KPTS/013/2011, Gubernur Jawa timur melarang aktivitas Jamaah Ahmadiyah Indonesia di seluruh wilayah Jawa Timur.

Hingga saat ini, Pemerintah Provinsi Jawa Timur dianggap gagal dalam melindungi komunitas Syiah Sampang yang menjadi korban kekerasan dan terusir dari kampung halamannya sejak tahun 2011. Alih-alih memberi perlindungan, Pemerintah Provinsi Jawa Timur justru mengeluarkan Peraturan Gubernur. No. 55 Tahun 2012 tentang Pembinaan dan Pengawawasan Aliran Sesat di mana dalam pasal 5 ayat (2) dinyatakan bahwa kegiatan keagamaan dikategorikan sebagai aliran sesat apabila memenuhi kriteria dan pertimbangan dari Majelis Ulama Indonesia (MUI).

\footnotetext{
8 Yayasan Lembaga Bantuan Hukum Indonesia, Wajah Buram Kebebasan Beragama dan Berkeyakinan di Tiga Provinsi: Pemantauan Peristiwa Pelanggaran Hak Kebebasan Beragama dan Berkeyakinan di Provinsi Jawa Barat, Jawa Timur dan DI Yogyakarta, 2016, hal 21.

9 Konflik adalah bentuk pertentangan alamiah yang dihasilkan oleh individu atau kelompok karena mereka yang terlibat memiliki perbedaan sikap, kepercayaan, nilai-nilai, serta kebutuhan.

10 Indeks Demokrasi Indonesia Tahun 2015, Bapennas dan UNDP.

ll Laporan Setara Institute Tahun 2016
} 
Peraturan Gubernur ini sangat krusial karena berpotensi melahirkan kekerasan terhadap pengikut Syiah sebagaimana yang terjadi pada warga Syiah Sampang, Madura. MUI Jawa Timur sendiri pada Januari 2012 telah mengeluarkan fatwa No. Kep-01/SKFMUI/JTM/I/2012 tentang Kesesatan Ajaran Syiah. Dengan demikian, Peraturan Gubernur ini telah dijadikan alat oleh beberapa kelompok tertentu di Jawa Timur untuk menentang kegiatan keagamaan yang diidentifikasi sebagai Syiah, misalnya, di Pasuruan, Puger Jember dan Bondowoso.

Kelompok minoritas lain yang terancam hak-haknya adalah LGBT. Sejak pembubaran Konferensi Regional International Lesbian and Gay Association (ILGA) di Jawa Timur 2010 yang diadakan di Surabaya, komunitas LGBT di Jawa Timur tidak berani terbuka menunjukkan identitasnya. Bahkan, kantor maupun tempat-tempat yang selama ini menjadi pertemuan di antara mereka menjadi sangat tertutup dan tersembunyi. Kecaman, diskriminasi, hingga ancaman fisik adalah cerita yang sangat mudah didapatkan dari komunitas ini. Bisa dibayangkan betapa rentannya komunitas ini menjadi korban pelanggaran HAM. Di samping itu kekerasan sebagai bagian pelanggaran HAM juga masih dialami oleh kelompok anak dan perempuan. Sebagaimana data kasus Dinas Sosial Provinsi Jawa Timur, di Jawa Timur terdapat 600 kasus kekerasan yang dialami oleh perempuan pada tahun 2016. ${ }^{12}$

\section{KOVENAN HAM TENTANG AGAMA DAN HAK MINORITAS}

Penikmatan atas agama merupakan bagian dari HAM. Oleh sebab itu, dalam Kovenan Internasional diatur tentang kebebasan beragama, misalnya dalam Deklarasi Universal Hak Asasi Manusia (DUHAM) 1948. Dalam DUHAM, istilah agama didefinisikan dalam Pasal 18 sebagai berikut:

"Everyone has the right to freedom of thought, conscience and religion; this right includes freedom to change his religion or belief, and freedom, either alone or in community with others and in public or private, to manifest his religion or belief in teaching, practice, worship and observance."13

Berdasarkan hukum kebiasaan Internasional (jus cogens dan international customary law), Indonesia tunduk kepada deklarasi tersebut, sebab deklarasi ini menjadi landasan bagi PBB untuk membuat kovenan dan perjanjian Internasional lainnya yang beberapa diantaranya juga telah diratifikasi oleh Indonesia. Hal yang sama juga diatur dalam Kovenan Internasional Hak-Hak Sipil dan Politik 1966 (ICCPR) dalam Pasal 18. Kovenan ini telah diratifikasi Indonesia dengan Undang-Undang Nomor 12 Tahun 2005.

12 Merdeka.com, "Jumlah perempuan korban kekerasan di Jatim masih tinggihttps://www.merdeka.com/peristiwa/jumlah-perempuan-korban-kekerasan-di-jatim-masihtinggi.html

13 Terjemahan dalam bahasa Indonesia, yang diberikan oleh Komisi Nasional Hak Asasi Manusia adalah sebagai berikut "setiap orang berhak atas kebebasan pikiran, hati nurani dan agama; dalam hal ini termasuk kebebasan berganti agama atau kepercayaan, dengan kebebasan untuk menyatakan agama atau kepercaaan dengan cara mengajarkannya, melakukan, beribadat dan mentaatinya, baik sendiri maupun bersama-sama dengan orang lain, di muka umum maupun sendiri. 
Kovenan lain yang mengatur dan memberikan jaminan hak atas kebebasan beragama dan berkeyakinan adalah Declaration on the Elimination of All Forms of Intolerence and of Discrimination Based on Religion or Belief 1981. Sedangkan dalam instrument nasional hak atas kebebasan beragama dan berkeyakinan dapat ditemukan dalam beberapa ketentuan Pasal dalam UUD NRI Tahun 1945, Undang-Undang Nomor 39 Tahun 1999 tentang Hak Asasi Manusia. Hak kebebasan beragama dan berkeyakinan (KBB) tersebut sudah diakui secara internasional maupun nasional sebagai salah satu elemen HAM yang tidak bisa dikurangi dan dibatasi (non-derogable rights), bahkan dalam keadaan perang dan keadaan darurat umum sekalipun, negara wajib untuk tidak mengintervensi apalagi memaksa. ${ }^{14}$

Hak kebebasan beragama/berkeyakinan dapat dibedakan menjadi dua kriteria. ${ }^{15}$ Pertama, forum internum yang terdiri atas hak untuk menganut agama atau keyakinan tertentu berdasarkan pilihannya sendiri, hak untuk memilih atau melakukan penafsiran keagamaan, dan hak untuk berpindah agama. Forum internum ini tidak boleh dibatasi, tidak boleh dikurangi dan tidak boleh dipaksa. Kedua, forum eksternum yang terdiri atas hak melakukan kegiatan ritual seperti ibadah/sembahyang atau upacara keagamaan, baik secara pribadi maupun bersama-sama serta baik secara tertutup maupun terbuka.

Forum eksternum juga mencakup hak untuk mendirikan tempat ibadah, hak untuk memungut iuran keagamaan, hak untuk menggunakan benda-benda ritual dan simbol-simbol agama, hak untuk merayakan hari besar agama, hak untuk menunjuk atau menetapkan pemuka agama, hak untuk mengajarkan agama dalam sekolah keagamaan, hak untuk menyebarkan ajaran agama, hak untuk mencetak dan mendistribusikan publikasi keagamaan, hak untuk mendirikan dan mengelola organisasi atau perkumpulan keagamaan, hak untuk membuat pengaturan makanan, hak berkomunikasi dengan individu atau kelompok di tingkat nasional dan internasional mengenai hal-hal keagamaan, hak untuk menggunakan bahasa keagamaan, hak orang tua untuk memastikan pendidikan agama kepada anaknya.

\section{SITUASI KEBEBASAN BERAGAMA DAN BERKEYANINAN (KBB) DI JAWA TIMUR}

Berdasarkan data pengaduan kasus KBB yang diterima Komnas HAM pada 2016 sepanjang 2016 ada 97 pengaduan yang masuk. Ada peningkatan pengaduan dibanding tahun 2015 yang tercatat sebanyak 87 pengaduan. Peningkatan angka ini dapat menjadi indikator: (a) ada peningkatan jumlah pelanggaran HAM atas kebebasan beragama dan

14 Abdul Fatah, Makalah, Potret Perlindungan Hukum dan Pemulihan terhadap Hak KBB di Jawa Timur, Dalam Seminar Sosial Keagamaan "Membangun Toleransi Antar Umat Beragama Demi Tegaknya NKRI" yang diselenggarakan Formacida dan PPAIK UMSurabaya, tanggal 21 Desember 2017.

15 ILRC, Panduan Pemantauan Tindak Pidana Penodaan Agama dan Ujaran Kebencian atas Dasar Agama, Jakarta, 2012, hlm 19. 
berkeyakinan dan/atau (b) meningkatnya kesadaran masyarakat untuk melaporkan kasus-kasus pelanggaran kepada Komnas HAM. ${ }^{16}$

Pelanggaran KBB di Jawa Timur dapat dilihat dari beberapa peristiwa berikut, pertama munculnya regulasi dan kebijakan yang diskriminatif berupa SK Gubernur No. 188/94/KPTS/013/201l tentang Larangan Aktivitas Ahmadiyah Jawa Timur, Pergub No. 55 Tahun 2012 tentang Pembinaan Kegiatan Keagamaan dan Pengawasan Aliran Sesat di Jawa Timur, kedua peristiwa konflik horizontal sunni dan Syiah di Sampang Madura yang berakibat terusirnya pengikut Syiah ke pengungsian. Data pengaduan kasus KBB pada Komnas HAM sebagaimana terlihat dalam tabel di bawah ini.

\section{Tabel Pengaduan KBB Komnas HAM Tahun 2016}

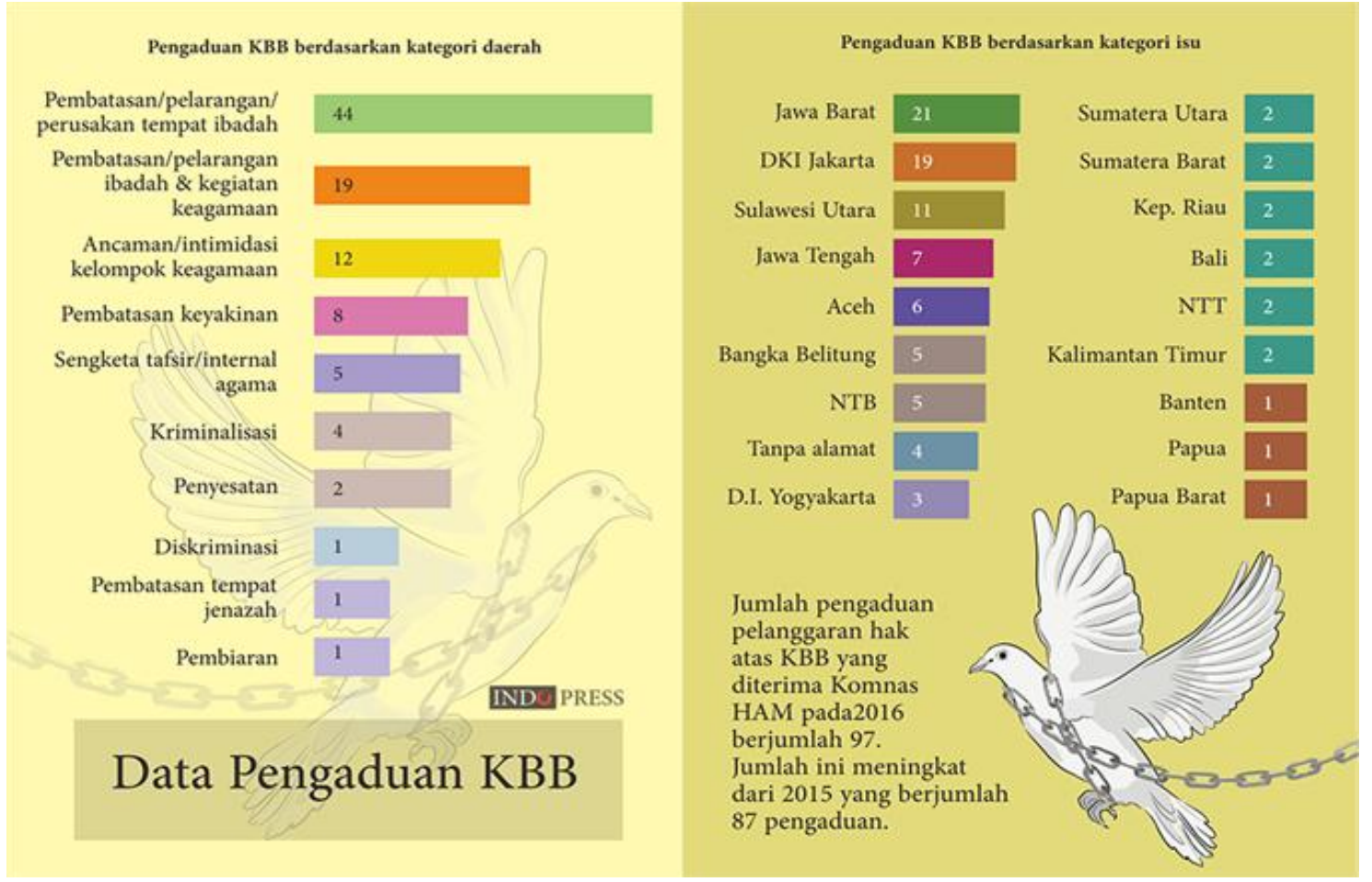

Sumber : www.indopress.id, diakses tanggal 11 Januari 2017

Berdasarkan hasil pemantauan Lembaga Bantuan Hukum (LBH) Surabaya sepanjang 2010-2015 saja terdapat 38 (tiga puluh delapan) kasus pelanggaran hak kebebasan beragama dan berkeyakinan di Jawa Timur. ${ }^{17}$ Bentuk-bentuk pelanggaran meliputi persekusi dan diskriminasi terhadap Jemaat Ahmadiyah, penyerangan dan kampanye anti Syiah, larangan aktivitas terhadap jemaat Majelis Tafsir Al Quran (MTA), larangan aktifitas terhadap penganut aliran kepercayaan, diskriminasi pelayanan administrasi kependudukan akibat identitas agama, masalah pendirian

16 Ahmad Zainul Hamdi, Makalah, Diskusi Berkala HAM dengan Komunitas Perempuan, Agama/keyakinan dan Etnis serta Inklusi Sosial Lainnya, LBH Surabaya, 26 April 2017.

17 Kertas Kebijakan LBH Surabaya, Mendorong Kebijakan Pananganan Konflik Sosial Berlatar Agama dan Keyakinan di Kabupaten Pasuruan, 2017, hal. 1. 
rumah ibadah dan tidak terpenuhinya pendidikan yang layak untuk anak-anak warga pengungsi Syiah Sampang.

Terjadinya pelanggaran KBB ini menurut Dr. Ahmad Zainul Hamdi disebabkan oleh pengingkaran kebhinnekaan yang meliputi 2 (dua) hal yaitu logika fungsionalisme struktural (kelompok berbeda sebagai penyakit dan musuh) dan politik manipulatif ruang publik (dari identitas daerah misal daerah santri, daerah sajadah, daerah tasbih sampai dengan peraturan daerah).

Implikasi nyata dengan adanya praktik pelanggaran KBB ini adalah terciptanya konflik komunal sebagaimana yang terjadi Sampang Madura dalam kasus konflik Sunni dan Syiah. Konflik Sampang Jawa Timur ini, telah menjadi konflik terbuka. Kasus ini berdampak pada terusirnya kelompok minoritas Syiah dari tempat tinggalnya, Desa Karangganyam, Kecamatan Omben, Kabupaten Sampang. Kasus tersebut bukanlah kasus tiba-tiba. Praktik kekerasan yang dialami oleh komunitas Syiah di Sampang telah terjadi sejak tahun 1980. Terjadi rentetan kekerasan yang berlangsung lama hingga memuncak pada penyerangan di bulan Agustus 2012, yang memakan korban jiwa dan harta benda. $^{18}$

\section{LANGKAH-LANGKAH PENTING SETELAH TERJADINYA PRAKTIK INTOLERANSI ATAS DASAR AGAMA DAN KEYAKINAN}

Persoalan konflik berlatar belakang agama atau konflik agama di Jawa Timur harus segera diselesaikan oleh negara c.q pemerintah. Penyelesaian konflik agama ini dimaksudkan untuk memberikan perlindungan dan pemenuhan hak konstitusional warga negara dan juga agar persolan ini tidak mengganggu kehidupan masyarakat.

Beberapa langkah dan strategi harus dilakukan secara bersama-sama semua pihak untuk menciptakan jalan keluar yang mengedepankan terpenuhinya dan terjaminnya HAM para korban. Strategi tersebut dimaksudkan agar tercapainya keadilan transisi. ${ }^{19}$ Langkah-langkah tersebut meliputi aspek upaya pengungkapan kebenaran dan penggunaan instrument negara untuk penanggulangan konflik sosial yang terjadi karena adanya pelanggaran KBB di Jawa Timur.

\section{A. Pengungkapan Kebenaran}

Terjadinya konflik terbuka atas nama agama dan keyakinan di Jawa Timur yang berakibat terjadinya pelanggaran HAM membutuhkan upaya pengungkapan kebenaran. Inisiatif pengungkapan kebenaran ini dibutuhkanuntuk membuka jalan keluar dan sebagai upaya refleksi di kemudian hari. Pengungkapan kebenaran diperuntukan untuk mengetahui penyebab dan motif terjadi konflik atas nama agama, kapan dan dimana terjadi, siapa sebagai pelaku, siapa yang menjadi korban, dan dimana

18 Kutipan presentasi Dr. Zainal Abidin Bagir dalam Diskusi Publik CRCS memperingati Hari Perdamaian Internasional (HPI) dan HTKI, Oktober 2012.

19 Keadilan transisi adalah kebenaran yang didasarkan adanya pencarian kebenaran dan adanya ruang rekonsiliasi semua pihak. 
posisi negara c.q pemerintah dalam kasus tersebut aktif melakukan pelanggaran (by comission) atau sengaja melakukan pembiaran (by omission).

Pengungkapan kebenaran ini menjadi penting dalam upaya pemulihan pasca konflik yang terjadi. Misal dalam kasus konflik Syiah Sampang sampai dengan saat ini belum ada pengungkapan kebenaran atas motif. Motif terjadinya konflik masih ambigu beberapa data lapangan menunjukan ada beberapa alasan kenapa konflik Syiah Sampang Terjadi, misalnya dalam konflik Sampang ini, beberapa analisis yang menjelaskan akar-akar konflik. Pertama, disebabkan adanya pernyataan-pernyataan tokoh agama yang menyebabkan intoleransi dan kebencian ini, merujuk pada fatwa Majelis Ulama Indonesia (MUI) Sampang, yang diperkuat oleh MUI Jawa Timur yang menyebutkan bahwa ajaran Syiah adalah sesat. ${ }^{20}$ Kedua, sebagian orang berpandangan bahwa konflik Sampang terjadi karena adanya persaingan internal keluarga yang berbeda faham, Rois (Sunni) dan Tajul Muluk (Syiah). Pengungkapan kebenaran ini perlu dilakukan sebagai upaya preventif agar tidak terjadi double burden (beban ganda) yang dialami oleh korban.

\section{B. Proses Peradilan yang Independen dan Tidak Memihak}

Setelah terjadinya konflik atas nama agama dan keyakinan yang mengakibatkan timbulnya korban dan pelanggaran HAM diperlukan proses peradilan yang independen dan tidak memihak. Proses peradilan ini diperuntukan untuk menghadirkan kebenaran berdasarkan obyektifitas peradilan yang dilakukan oleh hakim. Proses peradilan ini dilakukan agar tidak terjadi pelanggaran main hakim sendiri.

Satu hal penting dan harus dikedepankan dalam proses peradilan ini adalah menghadirkan peradilan yang benar-benar independen dan tidak memihak, harus imparsial. Peradilan yang dilakukan harus tunduk dan patuh pada ketentuan sistem peradilan pidana sebagaimana diatur dalam Undang-Undang Nomor 8 Tahun 1981 tentang Hukum Acara Pidana (KUHAP) dengan tetap memperhatikan hak-hak tersangka dan/atau terdakwa dengan memberikan perlindungan hukum terhadap saksi dan korban. Harmonisasi regulasi dan kebijakan yang mengatur urusan agama dan keyakinan harus melibatkan masyarakat dan tokoh lintas agama untuk dimaksudkan membangun kerukunan beragama dan berkeyakinan khususnya di Jawa Timur. ${ }^{21}$

\section{Pengarusutamaan Kesadaran Kolektif Pentingnya Keberagaman}

Salah satu penyebab terjadinya konflik atas nama agama dan keyakinan di Jawa Timur adalah tingkat kesadasaran masyarakat yang rendah dalam memandang pentingnya keberagaman dan dominasinya patron client. Oleh sebab itu upaya membangun

20 Tempo.com, "forum umat: Fatwa Sesat Syiah oleh MUI tidak sah" 31 Agustus 2012 http://www.tempo.co/ read/news/2012/08/31/078426687/Fotum-Umat-Fatwa-Sesat-Syiah-oleh-MUITidak-Sah.

21 Abdul Fatah, Membangun Daerah yang Toleran untuk Penganut Agama, Radar Surabaya, 21 Desember 2015. 
kesadaran kolektif akan pentingnya keberagaman menjadi penting untuk dilakukan pasca terjadinya konflik.

\section{Upaya Harmanisasi Regulasi dan Kebijakan Hukum}

Beberapa konflik atas nama agama dan keyakinan di Jawa Timur terjadi disebabkan adanya regulasi dan kebijakan hukum yang diskriminatif misalnya pertama munculnya regulasi yang diskriminatif berupa SK Gubernur No. 188/94/KPTS/013/2011 tentang Larangan Aktivitas Ahmadiyah Jawa Timur, Pergub No. 55 Tahun 2012 tentang Pembinaan Kegiatan Keagamaan dan Pengawasan Aliran Sesat di Jawa Timur, kedua peristiwa konflik horizontal sunni dan Syiah di Sampang Madura yang berakibat terusirnya pengikut Syiah ke pengungsian.

Regulasi dan kebijakan hukum tersebut bertentangan dengan UU No. 39 Tahun 1999 tentang Hak Asasi Manusia, UU 12 Tahun 2005 tentang Pengesahan Kovenan sipil Politik dan UUD NRI Tahun 1945. Sehingga pasca konflik perlu dilakukan harmonisasi regulasi dan kebijakan hukum di level daerah dengan peraturan perundang-undangan di atasnya. Harmonisasi ini penting untuk dilakukan khususnya terhadap pasal-pasal dalam KUHP yang mengatur keagamaan atau biasa disebut dengan Delik-delik Keagamaan dengan cara melakukan reformulasi dan rekontruksi Delik-Delik Keagamaan di Dalam RUU KUHP Indonesia yang saat ini sedang dibahas oleh Pemerintah bersama-sama dengan DPR RI. Delik-delik keagamaan yang subtansinya tendensiun dan overcriminalized dalam RUU KUHP Indonesia harus diminimalisir.

\section{E. Penggunaan Kebijakan Penanggulangan Konflik Sosial}

Berdasarkan realita penanganan konflik atas nama agama dan keyakinan di Jawa Timur masih terfokus pada jalur hukum litigasi semata atau upaya kriminalisasi melalui jalur pemidanaan. Padahal, jika merujuk pada UU No. 7 Tahun 2012 tentang Penyelesaian Konflik Sosial, dijelaskan bahwa upaya yang penting untuk dilakukan adalah berkaitan dengan sosial kemasyarakatan, baik dalam tahap rekonsiliasi, rehabilitasi, dan rekontruksi.

Berkaitan dengan upaya pascakonflik, pemerintah tidak melakukan langkahlangkah seperti yang telah ditentukan dalam UU No. 7 Tahun 2012 tentang Penyelesaian Konflik Sosial yaitu, yaitu rekonsiliasi, rehabilitasi, dan rekonstruksi oleh sebab itu konsolidasi komunal yang melibatkan semua pihak menjadi penting sebagai upaya pemulihan pasca konflik dengan mengedapan nilai-nilai kearifan lokal yang selama ini menjadi harta yang sangat berharga bagi masyarakat. Karena sebagaimana fakta empiris kasus syiah Sampang tidak segera selesai karena adanya pembatasan ruang keterlibatan semua pihak khususnya perempuan. ${ }^{22}$

22 Iva Hasanah dan Abdul Fatah, Suara Simpang Kasus Sampang: Konflik Sunni-Syiah Persepektif Perempuan, dalam M. Iqbal Ahnaf (editor), Praktik Pengelolaan Keragaman di Indonesia, Yogyakarta, CRCS UGM, 2015, hal 247 


\section{KESIMPULAN}

Penanganan konflik sosial yang terjadi atas nama agama dan keyakinan untuk menghadirkan keadilan transisi harus dilakukan dengan pelibatan semua pihak dengan maksud tercapainya konsolidasi komunal. Konsolidasi komunal ini dengan melibatkan beberapa pihak untuk bersama-sama mencari kebenaran atas problem utama atas terjadi konflik agama yang terjadi dan membangun proyeksi bersama sebagai bersama untuk rekonsiliasi. Dalam konsolidasi komunal tersebut, juga harus memperhatikan kearifan lokal daerah masing di Jawa Timur. Hal yang paling penting dalam penanganan konflik sosial atas nama agama adalah adanya kemampuan dan kemauan pemerintah untuk menyelesaikan konflik yang terjadi dengan tetap berpedoman pada UU No. 7 Tahun 2012 tentang Penyelesaian Konflik Sosial dengan memperhatikan aspek rekonsiliasi, rehabilitasi, dan rekonstruksi, sehingga pada akhirnya nanti akan tercapainya keadilan transisi dan keadilan transformatif.

\section{DAFTAR PUSTAKA}

Abdul Fatah, Makalah, Potret Perlindungan Hukum dan Pemulihan terhadap Hak KBB di Jawa Timur, Dalam Seminar Sosial Keagamaan "Membangun Toleransi Antar Umat Beragama Demi Tegaknya NKRI" yang diselenggarakan Formacida dan PPAIK UMSurabaya, tanggal 21 Desember 2017.

Abdul Fatah, Membangun Daerah yang Toleran untuk Penganut Agama, Radar Surabaya, 21 Desember 2015.

Ahmad Zainul Hamdi, Makalah, Diskusi Berkala HAM dengan Komunitas Perempuan, Agama/keyakinan dan Etnis serta Inklusi Sosial Lainnya, LBH Surabaya, 26 April 2017.

A. Saman Maggalatung, Makalah, Indonesia, Negara Hukum Demokrasi, Bukan Negara Kekuasaan Otoriter.

Indeks Demokrasi Indonesia Tahun 2015, Bapennas dan UNDP.

ILRC, Panduan Pemantauan Tindak Pidana Penodaan Agama dan Ujaran Kebencian atas Dasar Agama, Jakarta, 2012.

Iva Hasanah dan Abdul Fatah, Suara Simpang Kasus Sampang: Konflik Sunni-Syiah Persepektif Perempuan, dalam M. Iqbal Ahnaf (editor), Praktik Pengelolaan Keragaman di Indonesia, Yogyakarta, CRCS UGM, 2015.

Jimly Asshiddiqie, Hukum Tata Negara \& Pilar-Pilar Pilar Demokrasi, Serpihan Pemikiran Hukum, Media dan HAM, Jakarta: Konstitusi Press.

Kutipan presentasi Dr. Zainal Abidin Bagir dalam Diskusi Publik CRCS memperingati Hari Perdamaian Internasional (HPI) dan HTKI, Oktober 2012.

Kertas Kebijakan LBH Surabaya, Mendorong Kebijakan Pananganan Konflik Sosial Berlatar Agama dan Keyakinan di Kabupaten Pasuruan, 2017.

Laporan HAM Komisi Nasional Hak Asasi Manusia Tahun 2016.

Laporan Setara Institute Tahun 2016. 
M. Iqbal Ahnaf (editor), Praktik Pengelolaan Keragaman di Indonesia, Yogyakarta, CRCS UGM, 2015.

Majelis Permusyawaratan Rakyat RI, Panduan Pemasyaratakatan Undang-Undang Dasar Negara Republik Indonesia Tahun 1945 dan Ketetapan Majelis Permusyawaraatn Rakyat Republik Indonesia, Jakarta: Sekretariat MPR RI.

Merdeka.com, "Jumlah perempuan korban kekerasan di Jatim masih tinggihttps:/www.merdeka.com/peristiwa/jumlah-perempuan-korbankekerasan-di-jatim-masih-tinggi.html.

Padmo Wahyono, Pidato Pengukuhan sebagai Guru Besar Fakultas Hukum UI tanngal 17 November 1979. Seperti dikutip dalam bukunya sendiri, Indonesia Negara berdasarkan Atas Hukum, Jakarta: Ghalia Indonesia.

Tempo.com, "forum umat : Fatwa Sesat Syiah oleh MUI tidak sah" 31 Agustus 2012 http://www.tempo.co/read/news/2012/08/31/078426687/Fotum-Umat-FatwaSesat-Syiah-oleh-MUI-Tidak-Sah.

Yayasan Lembaga Bantuan Hukum Indonesia, Wajah Buram Kebebasan Beragama dan Berkeyakinan di Tiga Provinsi: Pemantauan Peristiwa Pelanggaran Hak Kebebasan Beragama dan Berkeyakinan di Provinsi Jawa Barat, Jawa Timur dan DI Yogyakarta, 2016. 